Jurnal MAKSIPRENEUR, Vol. I, No. 1, 2011, hal. 58-70

\title{
MODEL ELIMINASI KEMISKINAN MELALUI DEMOCRATIC-GOVERNANCE APPROACH BERBASIS LOCAL-RESOURCES DI ERA OTONOMI DAERAH
}

\author{
Bambang Sugeng Dwiyanto \\ Fakultas Ekonomi Universitas Proklamasi 45, Yogyakarta
}

ABSTRACT. Poverty is one of the main issues of Indonesian's social problems. This problem of poverty has been getting worse since the time of local autonomy, which brought serious imbalance in-between regions. However this problem can actually be solved if local government designed and implemented comprehensive and serious policies to battle poverty. Especially with democratic-governance based policies, which based on local-resources and local-wisdoms.

This research is focused onto local governments' effort in battling poverty. This research was done on two regions which acted as samples, the region of Kendal, and the region of Deli-Serdang. Based on this research, it can be qualitatively shown that policies that conform to the approach of democraticgovernance, which based on region's local-resources and local-wisdoms, are considerably effective in helping the local governments in their effort of battling poverty in their regions.

Keywords: democratic-governance, deli serdang, poverty, kendal, autonomy

\section{PENDAHULUAN}

Kemiskinan masih merupakan isu sentral di Indonesia. Menurut data dari Biro Pusat Statistik, pada tahun 2008, jumlah penduduk miskin sebanyak 34,96 juta, dan pada tahun 2009 ini, jika inflasi sebesar 6\% dengan pertumbuhan ekonomi sebesar 4,5\%, jumlah penduduk miskin diperkirakan sebanyak 29,99 juta jiwa. Tetapi jika inflasi sebesar $9 \%$ dengan pertumbuhan ekonomi sebesar 4,5\%, diperkirakan jumlah penduduk miskin sebesar 33,71 juta jiwa. 
Persoalan kemiskinan di Indonesia semakin diperburuk oleh ketimpangan antar daerah yang sangat serius dan semakin menguat di era otonomi daerah. Adanya politik otonomi daerah dan politik desentralisasi melalui Undang-Undang No. 22 Tahun 1999 yang direvisi oleh UndangUndang No. 32 Tahun 2004, memungkinkan pemerintah Daerah mendesain dan mengimplementasikan berbagai program pengentasan kemiskinan dan mengadakan inovasi pelayanan pro kaum miskin

Di antara sedikit daerah yang mendesain secara serius dan komprehensif berbagai program pengentasan kemiskinan itu adalah kabupaten Deli Serdang melalui Program Pengembangan Masyarakat Pesisir Mikro Mitra Mina, yang telah berhasil meningkatkan kesejahteraan masyarakat, terutama masyarakat pesisir. Kemudian pemerintah kabupaten Gorontalo, dengan Badan Usaha Milik Desa (BUMDes) PT. Agro Potombulu, telah berhasil meningkatkan kesejahteraan masyarakat di pedesaan, baik pemilik lahan pertanian maupun petani penggarap, sehingga secara bertahap dapat mengentaskan kemiskinan. Sementara pemerintah kabupaten Kendal, melalui pembentukan Badan Keswadayaan Masyarakat (BKM) melaksanakan Program P2KP yang berdampak cukup signifikan terhadap berkurangnya tingkat kemiskinan di kabupaten Kendal. Serta kabupaten Gianyar, yang dengan Program Gianyar Sejahtera telah berhasil meningkatkan pembangunan ekonomi masyarakat dan mengentaskan kemiskinan.

Keberhasilan dari beberapa daerah dalam melaksanakan program pengentasan kemiskinan sebenarnya dapat digunakan sebagai model bagi daerah lain. Penelitian ini akan mengkaji lebih mendalam tentang program pengentasan kemiskinan di dua daerah dari berbagai daerah tersebut, yaitu berkaitan dengan bagaimana situasi sebelum adanya program tersebut, bagaimana proses inisiasi dan strategi pelakasanaan program-program tersebut, hasil yang dicapai dan manfaat yang diperoleh dari program tersebut, dan sebagainya. Dengan kajian tersebut, diharapkan dapat dilakukan abstraksi dalam sebuah kebijakan atau model yang dapat dijadikan pedoman bagi daerah-daerah lain dalam melaksanakan program pengentasan kemiskinan. Berdasarkan uraian di muka, maka pertanyaan yang akan dijawab dalam penelitian adalah sebagai berikut: "Bagaimanakah model pengentasan kemiskinan yang menggunakan democratic-governance approach berbasis local resources atau local wisdom?"

Penelitian ini penting dilakukan, karena berbagai penelitian yang pernah dilakukan oleh lembaga penelitian pemerintah, Bank Dunia, dan institusi-institusi think-tank terhadap berbagai program pengentasan kemiskinan yang dilakukan oleh pemerintah pusat maupun pemerintah daerah mempunyai kecenderungan bersifat parsial, yaitu hanya mengkaji aspek subtansi atau isi dari kebijakan. Sementara, penelitian ini, juga akan 
mengkaji aspek proses dan konteks dari setiap kebijakan penanganan kemiskinan yang ada.

Penelitian ini juga akan mengkaji sejauh mana program-program pengentasan kemiskinan itu mempertimbangkan dan melibatkan sumber daya dan nilai-nilai kearifan lokal, serta sejauh mana program pengentasan kemiskinan tersebut melibatkan masyarakat dan sektor swasta, sehingga peran pemerintah hanya menjadi satu dari beberapa faktor dan tidak selalu menjadi faktor paling menentukan.

\section{KERANGKA TEORITIS}

Penelitian tentang kebijakan penanganan kemiskinan di Indonesia era otonomi daerah sangat beragam corak pendekatannya serta digunakan untuk kepentingan yang berbeda-beda. Beberapa penelitian digunakan sebagai bagian dari kajian akademik tentang kemiskinan di Indonesia adapula yang digunakan untuk evaluasi penerapan kebijakan.

World Bank-INDOPOV (2006) melakukan penelitian terhadap daerah-daerah otonom yang dianggap berhasil mengembangkan berbagai bentuk pelayanan publik dasar yang pro orang miskin. Penelitian ini memfokuskan kajian pada bagaimana pengaruh kepemimpinan terhadap dinamika inovasi pelayanan publik untuk kaum miskin. Tentu saja kajian ini tidak cukup bisa menjawab pertanyaan mengapa banyak daerah yang lain dengan kapasitas kepemimpinan yang kuat namun gagal menginstitusionalisasi inovasi pelayanan publik.

Penelitian tentang kemiskinan di Indonesia pasca otonomi daerah juga pernah dikemukakan oleh SMERU Institute (2007). Kajian ini memfokuskan penelitian pada Program Operasi Pasar Swadaya (OPSM) yang disponsori oleh World Food Programme. Kajian ini mengingatkan kita bahwa sebuah program penanggulangan kemiskinan harus dikelola berkesinambungan, sebuah program penanggulangan kemiskinan memiliki kaitan dengan program yang lainnya dan durasinya bukan hanya pada saat program itu dilakukan saja.

Karakter good-governance yang dirumuskan oleh lembaga-lembaga internasional berangkat dari sebuah pemikiran yang mendekat ke gagasan liberal. Pemerintahan (government) yang dianggap terlalu menekankan pada kewenangan pemerintah, harus diganti dengan kepemerintahan (governance) yang menekankan kepada hubungan timbal balik antar tiga pilar: pemerintah, civil society dan pelaku bisnis (Rhodes,1996). Dalam pengertian ini, pemerintahan yang baik menuntut peran pemerintah yang minimal dan meniru logika pasar.

Dari sisi proses, pemerintahan yang baik adalah yang partisipatif, berorientasi ke konsensus, transparan, akuntabel, bersih, efektif dan efisien, responsif, dan mengembangkan kepastian hukum. Tetapi sebaiknya, 
terhadap karakter pemerintahan yang baik semacam ini perlu diberikan beberapa catatan penting.

Pertama, karakter-karakter ini harus dipahami dalam konteks untuk menjamin pemerintahan yang menjamin pemerataan dan akses masyarakat terhadap pelayanan yang baik. Kedua, karakter proses pemerintahan yang baik ini perlu mengalami kontekstualisasi dengan kondisi sosio-kultural pada masyarakat setempat. Catatan kedua ini penting apabila kita berbicara dalam konteks pemerintahan di tingkat lokal yang perbedaan antar pilar governance (state, civil society $\mathcal{E}$ business) tidak jelas.

Karenanya, bagi mayoritas masyarakat Indonesia yang notabene mayoritas miskin, pemerintahan yang baik adalah pemerintahan yang mengarah pada penjaminan standar pelayanan dasar, pemerataan dan berkeadilan. Untuk itu diperlukan peran dan kapasitas negara untuk menjamin kesempatan yang setara dan relasi yang berkeadilan dan demokratis.

Dengan prinsip democratic-governance, proses kebijakan (termasuk kebijakan dalam pengentasan kemiskinan), harus dilandasi dengan prinsip desentralisasi dan demokrasi. Dalam proses kebijakan yang desentralistik dan demokratis ini, semangat utamanya adalah partisipasi.

Pemaknaan ide partisipasi dalam proses kebijakan di aras lokal sangat luas dan beragam. Partisipasi dalam proses kebijakan di aras lokal mesti dimengerti tidak sebagai tujuan semata. Ia harus dimaknai sebagai sarana untuk mewujudkan kebijakan perencanaan pembangunan daerah yang pro publik dan sensitif dengan konteks.

Derajat partisipasi dalam proses kebijakan bisa kita kategorisasikan ada 3 tingkat derajat (Hanif \& Kurniawan, 2007), yaitu: (1) invited space; keterlibatan warga dalam proses perencanaan muncul dikarenakan ruang yang disediakan oleh pemerintah daerah. (2) conquered space; penyediaan ruang bagi keterlibatan warga yang dilembagakan dalam proses perencanaan pembangunan daerah. (3) popular space; partisipasi publik terlembagakan secara apik dan mempengaruhi seluruh proses perencanaan pembangunan daerah yang ada.

Kearifan lokal adalah jawaban kreatif terhadap situasi geografisgeopolitis, historis, dan situasional yang bersifat lokal. Dan berdasarkan elaborasi konsep di atas, maka kebijakan dan program pengentasan kemiskinan dalam konteks democratic-governance berbasis local-resources dan local-wisdom merupakan kebijakan dan program pengentasan kemiskinan yang didesain dengan mekanisme bottom-up, memberi ruang pada partisipasi masyarakat, sektor swasta dan negara (pemerintah kabupaten) baik dalam tataran kebutuhan maupun dalam tataran proses penentuan program, mendasarkan diri pada potensi sumber-sumber yang ada di daerah bersangkutan, baik sumber daya alam, sumber daya manusia maupun nilai dan budaya setempat. 


\section{METODE PENELITIAN}

Metode kajian yang digunakan adalah metode deskriptif dengan menggunakan Analisis kualitatif. Penelitian deskriptif bertujuan untuk mendeskripsikan atau melukiskan realitas sosial yang kompleks yang ada dalam masyarakat. Konsekuensi logis dari dipakainya metode deskriptif ini adalah penggunaan aplikasi penelitian kualitatif, termasuk penggunaan metode wawancara dan dokumentasi(Molleong, 1994).

Penelitian dilakukan di wilayah yang dipilih secara purposive sampling, yaitu kabupaten yang selama era otonomi daerah telah menjadi bestpractices bagi daerah-daerah lain dalam program pengentasan kemiskinan, kabupaten-kabupaten tersebut adalah:

1. Kabupaten Deli Serdang (Provinsi Sumatera Utara).

2. Kabupaten Kendal (Provinsi Jawa Tengah).

Adapun pertimbangan dalam memilih kedua kabupaten tersebut adalah karena keberhasilan kabupaten-kabupaten yang mewakili wilayah pesisir pantai tersebut dalam menjalankan program pengentasan kemiskinan dengan menggunakan pendekatan democratic-governance berbasis local wisdom.

\section{DATA PENELITIAN}

Dalam penelitian ini, ada dua jenis data yang dibutuhkan yaitu:

1. Data primer yang dikumpulkan secara langsung dari lapangan pada lokasi penelitian.

2. Data sekunder yang berupa naskah kebijakan, peraturan perundangundangan, laporan pelaksanaan kebijakan atau MoU yang dimiliki oleh kedua pemerintah kabupaten yang menjadi sampel penelitian.

\section{TEKNIK PENGUMPULAN DATA}

Teknik pengumpulan data yang dilakukan dalam penelitian ini yaitu:

1. Desk-study yang dilakukan terhadap berbagai informasi dan hasil penelitian sejenis yang telah dilakukan sebelumnya, serta berbagai teori yang terkait dengan kemiskinan. Dilakukan juga review atas program pengentasan kemiskinan yang dilakukan oleh kedua kabupaten.

2. Focused Group Discussion (FGD) yang dilakukan terhadap para policymaker dan stakeholders program pengentasan kemiskinan di kedua kabupaten, dengan tujuan mengkaji skema pemikiran para policy-maker 
dan stakeholders. FGD juga dimaksudkan untuk melakukan cross-check atas berbagai hasil kajian dokumen yang telah dilakukan.

3. Indepth-interview yang dimaksudkan untuk mengklarifikasi beberapa inkonsistensi yang muncul dalam FGD. Serta untuk menyingkap 'ideologi’ di balik program pengentasan kemiskinan yang dilaksanakan.

\section{METODE ANALISIS DATA}

Berbagai data dan informasi yang terkumpul kemudian di secara kualitatif, dengan langkah-langkah sebagai berikut:

1. Menelaah seluruh data dari berbagai sumber yang diperoleh melalui wawancara, observasi dan dokumentasi.

2. Melakukan reduksi data dengan melakukan abstraksi atau rangkuman.

3. Melakukan teknik triangulasi dan kasus negatif untuk meningkatkan reliabilitas temuan dan validitas .

4. Melakukan identifikasi pelaksanaan program pengentasan kemiskinan.

5. Meng pengaruh timbal balik rencana dan tujuan dengan hasil dari program pengentasan kemiskinan.

6. Meng sinergi antar stakeholders dalam pelaksanaan program pengentasan kemiskinan.

\section{VII. \& PEMBAHASAN}

\section{A. Program Penanggulangan Kemiskinan Perkotaan (P2KP) Di Kabupaten Kendal}

Wilayah kabupaten Kendal secara administratif terdiri dari 19 kecamatan, 20 kelurahan, dan 265 desa, dengan jumlah penduduk 49,34\% laki-laki dan 50,66\% perempuan, dengan kepadatan penduduk 261 jiwa $/ \mathrm{Km}^{2}$.

Persoalan yang dialami oleh kabupaten Kendal adalah masalah kemiskinan. Apalagi, kabupaten ini berbatasan langsung dengan ibukota Jawa Tengah, Semarang, sehingga kesenjangan sosial dengan mudah terlihat dan terbandingkan. Menyadari situasi itu, pemerintah kabupaten Kendal pun memfokuskan pembangunannya pada pengentasan kemiskinan, yang penanganannya direncanakan melalui Strategi Penanggulangan Kemiskinan Daerah (SKP-D) kabupaten Kendal.

Berangkat dari diterapkannya Otonomi Daerah, pemerintah kabupaten Kendal dituntut untuk membuat dan melaksanakan sendiri program pembangunan daerah yang memuat kebijakan secara terinci dan terukur. Bagi pemerintah kabupaten Kendal, Program Penanggulangan Kemiskinan Perkotaan (P2KP) bukanlah hal baru. Dan setelah mempelajari dan meneliti kegagalan program $\mathrm{P}_{2} \mathrm{KP}$ terdahulu yang berpola top-down, pemerintah kabupaten Kendal pun berkesimpulan perlu dibentuknya satu 
lembaga yang melibatkan banyak pihak, yaitu Badan Keswadayaan Masyarakat (BKM).

BKM ini didirikan di tingkat desa/kelurahan, dengan tugas utama membantu pemerintah mengentaskan kemiskinan masyarakat, dengan cara menumbuhkan dan mengembangkan ekonomi lokal disaat terjadinya krisis multidimensi. Antara lain, dengan menyelenggarakan pelatihan keterampilan manajemen, mengelola usaha kecil dan memberikan pinjaman modal kepada masyarakat miskin, agar mampu memecahkan dan mengatasi masalahnya sendiri.

Sebelum BKM beroperasi, pemerintah kabupaten Kendal melakukan sosialisasi, baik melalui media (surat kabar lokal), pertemuan di balai desa, maupun pamflet dan selebaran. Sosialisasi ini melibatkan instansi pemerintah, LSM, dan tokoh masyarakat lainnya. Pada tahap awal pelaksanaan program di tahun 2006, pemerintah kabupaten Kendal membentuk 7 BKM di 7 desa, yang kemudian berkembang menjadi 23 BKM di 23 desa pada tahun 2008. Keberadaan BKM di desa sangat bermanfaat dan berarti bagi masyarakat, terutama bagi masyarakat usaha kecil. Hal ini disebabkan karena masyarakat dapat memperoleh pinjaman usaha kelompok maupun perseorangan tanpa menggunakan agunan.

Sebagai langkah awal, dana BKM yang berasal dari dana hibah program P2KP sebesar Rp 1,7 milyar didistribusikan kepada 23 BKM yang tersebar di 23 desa. Selanjutnya, BKM sebagai lembaga pengelola keuangan memiliki kewenangan mengelola dana hibah tersebut.

Namun demikian, konsep ini tak terlepas dari kendala. Saat awal program ini digulirkan ternyata banyak sekali masyarakat, perorangan maupun kelompok, yang meminjam modal kerja kepada BKM, sehingga dana yang tersimpan di BKM tidak mencukupi. Kendala lainnya, sejumlah masyarakat peminjam menganggap modal tersebut tidak perlu dikembalikan karena dianggapnya merupakan dana hibah.

Untuk mengatasi masalah itu, akhirnya pemerintah kabupaten Kendal dan BKM memutuskan untuk memperketat pemberian pinjaman dengan memberikan beberapa persyaratan dan melakukan survei. Selain itu, sosialisasi pun terus dilakukan, untuk memberikan pemahaman dan kesadaran masyarakat, agar mengembalikan modal bergulir tersebut.

Salah satu BKM yang cukup berhasil di kabupaten Kendal adalah BKM "Kurnia Jaya" yang terletak di Desa Cepiring, Kecamatan Cepiring. Indikatornya, BKM Kurnia Jaya berhasil dalam menambah permodalan dan menjawab tuntutan masyarakat kalangan menengah. Cara yang dilakukan oleh BKM Kurnia Jaya adalah dengan memberikan pinjaman kelompok yang diperuntukkan bagi warga kurang mampu dengan dikenai jasa sebesar 1,5\% flat/bulan; sedangkan pinjaman perorangan diperuntukkan bagi warga kelas menengah dengan menggunakan agunan dan dikenai jasa sebesar 3\% flat/bulan. 
Melalui program BKM Kurnia Jaya ini, ternyata tingkat kemiskinan di Desa Cepiring menurun. Hal ini disebabkan modal kerja yang dipinjamkan BKM Kurnia Jaya dipergunakan dengan sangat baik dan terarah, sehingga tingkat keberhasilan usaha cukup tinggi. Sebagai ilustrasi keberhasilan BKM dalam pengentasan kemiskinan berikut ini data keluarga miskin di kabupaten Kendal.

Tabel 1. Data Keluarga Kabupaten Kendal

\begin{tabular}{|r|c|c|c|c|c|c|c|c|c|c|c|}
\hline \multirow{2}{*}{ KECAMATAN } & Jml.total & \multicolumn{10}{|c|}{ Jumlah keluarga (KK) } \\
\cline { 3 - 12 } & KK $^{*}$ & Pra KS & $\%$ & KS1 & $\%$ & KS2 & $\%$ & KS3 & $\%$ & KS3+ & $\%$ \\
\hline 2008 & 240.482 & 121.344 & 51,03 & 33.086 & 13,76 & 28.432 & 11,82 & 49.700 & 20,67 & 5.420 & 2,254 \\
\hline 2007 & 235,214 & 123.356 & 53,19 & 31.086 & 13,4 & 26.489 & 11,42 & 49.116 & 21,18 & 5.157 & 2,23 \\
\hline 2006 & 231,901 & 124.635 & 53,74 & 29.586 & 12,76 & 25.866 & 11,15 & 46.898 & 20,22 & 4.916 & 2,12 \\
\hline
\end{tabular}

Sumber data: Kantor BKKBCS Kab. Kendal /Evaluasi Kinerja Pemerintah Ketr: *) Pra KS = Keluarga Miskin

Pembentukan BKM yang dikelola pemerintah kabupaten Kendal sangat memungkinkan untuk dicontoh daerah lain. Hal-hal yang dapat ditransfer kepada pemerintah daerah lainnya di Indonesia adalah:

1. Strategi pemerintah kabupaten dengan membentuk forum komunikasi dan menyelenggarakan pelatihan berkenaan dengan pengelolaan BKM.

2. Mekanisme pengembangan partisipasi masyarakat yaitu Pemda mengajak masyarakat untuk terlibat secara aktif dalam mensosialisasikan BKM.

3. Mekanisme membangun kepercayaan masyarakat melalui sosialisasi menyeluruh.

4. Penyediaan sarana-prasarana penunjang pembentukan BKM.

5. Dasar hukum kuat dari pemerintah kabupaten yang sesuai dengan kebutuhan lokal.

\section{B. Program Pengentasan Kemiskinan Melalui Pemberdayaan Ekonomi Masyarakat Pesisir Di Kabupaten Deli Serdang}

Secara ekonomis, potensi unggulan daerah yang dimiliki Kabupaten Deli Serdang bertumpu pada 4 (empat potensi), yaitu potensi pertanian, industri, pariwisata, dan potensi sumber daya alam lainnya. Struktur Ekonomi Kabupaten Deli Serdang dapat dilihat pada Tabel 2.

Tabel 2. Struktur Perekonomian di Kabupaten Deli Serdang

\begin{tabular}{|l|l|l|}
\hline Uraian & 2007 & 2008 \\
\hline Sektor & $49.43 \%$ & $48.86 \%$ \\
\hline Sektor & $38.37 \%$ & $29.80 \%$ \\
\hline Sektor Jasa & $12.20 \%$ & $11.34 \%$ \\
\hline & $100 . \%$ & $100 . \%$ \\
\hline
\end{tabular}


Ketika menentukan ukuran atau kriteria kemiskinan, ukuran yang digunakan adalah sejauh mana individu memenuhi kebutuhan-kebutuhan dasarnya. Selama ini ukuran yang seringkali digunakan adalah:

1. Konsumsi beras per kapita per tahun $(\mathrm{kg})$

2. Tingkat pengeluaran ekuivalen per orang per tahun

3. Kebutuhan gizi minimum per orang per hari

4. Pendapatan minimum kapita per tahun

5. Pengeluaran per kapita per bulan

Menggunakan ukuran-ukuran tersebut, ditampilkan data jumlah penduduk miskin di Kabupaten Deli Serdang tahun 2008 pada tabel 2.

Tabel 3. Jumlah Penduduk Miskin Kabupaten Deli Serdang (Tahun 2007)

\begin{tabular}{|l|c|}
\hline \multicolumn{1}{|c|}{ Kecamatan } & $\begin{array}{c}\text { Jumlah Penduduk } \\
\text { Miskin (orang) }\end{array}$ \\
\hline Gunung Meriah & 926 \\
\hline STM Hulu & 4581 \\
\hline Sibolangit & 7778 \\
\hline Kutalimbaru & 13493 \\
\hline Pancur Batu & 30447 \\
\hline Namorambe & 10135 \\
\hline Biru-biru & 12233 \\
\hline STM Hilir & 11136 \\
\hline Bangun Purba & 13773 \\
\hline Galang & 25190 \\
\hline Tanjung Morawa & 65010 \\
\hline Patumbak & 27404 \\
\hline Deli Tua & 20976 \\
\hline Sunggal & 80266 \\
\hline Hamparan Perak & 52217 \\
\hline Labuhan Deli & 20015 \\
\hline Percut Sei Tuan & 123367 \\
\hline Batang Kuis & 18144 \\
\hline Pantai Labu & 16273 \\
\hline Beringin & 19391 \\
\hline Lubuk Pakam & 34254 \\
\hline Pagar Merbau & 12751 \\
\hline Jumlah & 619762 \\
\hline
\end{tabular}

Sumber: Kabupaten Deli Serdang dalam Angka 
Kondisi nelayan di Kabupaten Deli Serdang cukup memprihatinkan lantaran jumlah pendapatannya yang rendah. Terjadinya kemiskinan ini disebabkan beberapa hal:

1. Nelayan di wilayah kabupaten Deli Serdang umumnya merupakan kelompok yang sangat sulit untuk diorganisasi. Mereka merupakan kelompok masyarakat yang belum memiliki konsep perencanaan ekonomi yang pasti dan bersifat jangka panjang.

2. Nelayan di Kabupaten Deli Serdang juga belum banyak tersentuh dengan program-program yang dapat mengembangkan ekonomi mereka secara riil, terorganisasi dan berkelanjutan.

Melihat situasi dan kondisi nelayan ini, pada tahun 2008 Pemerintah Pusat meluncurkan program PEMP (Pemberdayaan Ekonomi Masyarakat Pesisir) yang secara khusus diarahkan untuk peningkatan dan pemberdayaan ekonomi masyarakat nelayan di wilayah pesisir.

Menyikapi kondisi kemiskinan yang dialami nelayan ini, Pemerintah Kabupaten Deli Serdang melakukan beberapa upaya inisiatif untuk membantu mengatasinya, yakni:

1. Dengan memanfaatkan keberadaan program PEMP, diperkenalkan berbagai inovasi teknik penangkapan ikan yang aman dan ramah lingkungan dan dengan hasil yang lebih optimal.

2. Pengorganisasian nelayan melalui pembentukan lembaga yang difasilitasi oleh Pemerintah kabupaten. Lembaga nelayan tersebut digunakan sebagai wadah penciptaan lapangan usaha dan pemberian fasilitas kredit dan simpan-pinjam.

Sebagai upaya pelaksanaan pendampingan bagi masyarakat, pihak Pemerintah kabupaten bersama masyarakat pesisir di Percut Sei Tuan membentuk sebuah lembaga bernama LEPP-M3 (Lembaga Ekonomi Pengembangan Pesisir Mikro Mitra Mina). Selanjutnya, LEPP-M3 merekrut seorang Staff Pendamping yang memahami sistem perikanan dan kelautan, dan sistem distribusi perdagangan.

Dana Pemerintah kabupaten dikelola secara efektif melalui manajemen sederhana dan disalurkan pada pelaksanaan 5 sub-program, yaitu:

1. Pengadaan 14 unit kapal penangkap ikan;

2. Pemberian modal usaha pembudidayaan ikan dan udang kepada 20 unit tambak.

3. Pemberian modal usaha untuk pengolahan ikan sebanyak 2 unit.

4. Pemberian modal usaha untuk pengadaan BBM sebanyak 1 unit; 
5. Pemberian modal usaha untuk usaha bakulan sebanyak 10 orang.

Selain pemberian modal usaha, LEPP-M3 juga memberikan peluang bagi anggota binaannya untuk melakukan kegiatan simpan pinjam. Setiap anggota memiliki hak untuk meminjam dana yang tersedia di LEPP-M3 dengan persyaratan yang bersangkutan tidak memiliki tunggakan dan yang bersangkutan dapat membayar cicilan tepat waktu. Dana pinjaman dapat digunakan sebagai tambahan modal kerja dengan plafon maksimal sebesar Rp1 juta.

LEPP-M3 tidak hanya menjadi mitra Pemerintah Kabupaten dalam melaksanakan pemberdayaan masyarakat pesisir, tapi juga menjadi laboratorium pengembangan teknologi penangkapan ikan. Dinas Perikanan mengembangkan sebuah alat penangkap ikan yang efektif yaitu "Pukat Layang", yang lebih ramah lingkungan ketimbang "Pukat Harimau". "Pukat Layang" diujicobakan pada masyarakat nelayan di bawah koordinasi LEPPM3.

Keberhasilan LEPP-M3 Imendapatkan perhatian khusus dari pemerintah pusat dengan adanya program "Subsidi BBM" untuk nelayan yang diberikan melalui penyediaan SPBU khusus bagi nelayan, sehingga nelayan bisa membeli BBM dengan potongan harga yang cukup besar. SPBU-Nelayan ini dikelola oleh LEPP-M3 dan merupakan satu-satunya SPBU Nelayan di wilayah Sumatera.

Walaupun progran PEMP merupakan sebuah program luncuran dari Pemerintah Pusat, namun pemerintah kabupaten Deli Serdang telah berhasil mengembangkan program-program inovatif yang disesuaikan situasi dan kondisi lokal. Selama Pemerintah Daerah memiliki komitmen yang tinggi untuk memfasilitasi dan memberikan pelayanan peningkatan kesejahteraan masyarakat, serta berupaya membangun kemitraan dengan pihak-pihak terkait, ternyata efektif dalam mengurangi jumlah penduduk miskin dari 619.762 jiwa menjadi 365.660 jiwa atau turun 254.102 jiwa atau $41 \%$, maka program pemberdayaan masyarakat pesisir seperti yang telah dilakukan di Deli Serdang menjadi sangat layak untuk dapat ditransfer kepada pemerintah daerah lainnya di Indonesia.

\section{KESIMPULAN}

Persoalan kemiskinan di Indonesia yang diperburuk oleh ketimpangan antar daerah terutama di era otonomi daerah, ternyata dapat diatasi jika pemerintah daerah dapat mendesain dan mengimplementasikan berbagai program pengentasan kemiskinan yang serius, dan komprehensif.

Contoh dari daerah yang relatif berhasil dalam usaha pengentasan kemiskinan adalah kabupaten Kendal, dan kabupaten Deli Serdang, di mana kedua kabupaten tersebut berhasil mengentaskan kemiskinan dengan 
kebijakan yang berprinsip democratic governance, dan berbasis localresources dan local-wisdom.

Kabupaten Kendal memicu program pengentasan kemiskinan yang bersifat bottom-up dari tingkat desa melalui lembaga Badan Keswadayaan Masyarakat (BKM). Dibarengi dengan, pengelolaan lembaga, sosialisasi, dan pelatihan masyarakat yang komprehensif, BKM berhasil menjadi fasilitator usaha masyarakat, dan berperan besar dalam menaikkan derajat ekonomi masyarakat pedesaan di kabupaten Kendal, sehingga penduduk miskinnya berkurang sekitar 3.291 kepala kekuarga.

Di kabupaten Deli Serdang, pengentasan kemiskinan didorong mulai dari pemberdayaan masyarakat nelayan pesisir melalui program Pemberdayaan Ekonomi Masyarakat Pesisir (PEMP), yang tidak hanya memberikan fasilitas pinjaman modal usaha, namun juga pengorganisasian masyarakat, fasilitas penyediaan BBM bersubsidi untuk nelayan, dan inovasi teknologi penangkapan ikan. Progaram ini berhasil menekan kemiskinan sampai $41 \%$.

\section{SARAN}

Mengkaji kebijakan pengentasan kemiskinan yang dilaksanakan kedua daerah, dapat dilihat bahwa kebijakan yang dirumuskan berdasarkan prinsip democratic governance, dan berbasis local-resources dan localwisdom, ternyata relative lebih efektif dan tepat sasaran.

Oleh karena itu, penulis menyarankan agar pemerintah daerah di Indonesia mengembangkan model democratic-governance berbasis localresources dan local wisdom dalam merumuskan kebijakan dan program pengentasan kemiskinan. Yaitu program pengentasan kemiskinan yang memberi ruang pada partisipasi masyarakat, sektor swasta dan Negara (pemerintah daerah), baik dalam tataran kebutuhan maupun dalam tataran proses penentuan program, dengan mendasarkan diri pada potensi sumbersumber yang ada di daerah bersangkutan, baik sumber daya alam, sumber daya manusia maupun nilai dan budaya setempat.

\section{DAFTAR PUSTAKA}

Hanif, Hasrul dan Nanang Indra Kurniawan. 2007. "Mengarusutamakan Partisipasi Dalam Proses Kebijakan di Pemerintahan Daerah”, dalam Arie Ruhyanto (ed.), Merajut Good Governance dalam Penyelenggaraan Pemerintahan Daerah (Yogyakarta: World Bank Institute-S2 PLOD UGM).

Molleong, Lexy J. 1994. Metodologi Penelitian Kualitatif. Bandung: Remaja Rosda Karya. 
Rhodes, R.A.W. 1996. "The New Governance: Governing Without Government", dalam Jurnal Political Studies, Vol. 44, No. 4, September 1996.

SMERU Institute. 2007. Strategi Mengakhiri Program: Pengalaman Program Penanggulangan Kemiskinan di Indonesia. Jakarta; SMERU Institute

World Bank-INDOPOV. 20o6. Inovasi Pelayanan Pro-Miskin: Sembilan Studi Kasus di Indonesia. Jakarta: World Bank. 